\title{
Augmented cytotoxic, mutagenic and genotoxic response triggered by carvedilol and celecoxib combinations
}

\author{
Ali Attiq ${ }^{*}$, Muhammad Ashraf², Juriyati Jalil', Aqeel Javeed², Aftab Ahmad Anjum³, Asad Ullah², \\ Muhammad Umair ${ }^{2}$, Sarwat Ali \\ ${ }^{1}$ Drug and Herbal Research Center, Faculty of Pharmacy, Universiti Kebangsaan Malaysia, Jalan Raja Muda Abdul Aziz, \\ Kuala Lumpur, Malaysia, ${ }^{2}$ Department Of Pharmacology and Toxicology, University of Veterinary and Animal Sciences, \\ (UVAS) Syed Abdul Qadir Jillani (Out Fall) Road, Lahore, Pakistan, ${ }^{3}$ Department of Microbiology, University of Veterinary \\ and Animal Science (UVAS) Syed Abdul Qadir Jillani (Out Fall) Road, Lahore, Pakistan
}

\begin{abstract}
It is understood that drugs regardless of their order of administration can exhibit drug interactions. Established on the fact that treatment of hypertension may last for decades and prolong usage of multiple drug regimen may induce substantial pathophysiological changes. Hence, This study was designed to evaluate the possible synergistic toxic effects of anti-hypertensive (carvedilol), and anti-inflammatory drug (celecoxib) alone and in combinations. Well-established MTT assay, Single Cell Gel Electrophoresis (SCGE) and Ames assay were employed to evaluate the toxicity at cellular level. Results from MTT assay on Vero cell line revealed that drug combinations have more pronounced anti-proliferative activity with combine $\mathrm{IC}_{50}$ value of 13.7:47.8 $\mu \mathrm{g} / \mathrm{mL}$. Likewise, exposure of peripheral blood mononuclear cells with drug combinations revealed significant $(\mathrm{P}<0.05)$ DNA damage (Class 3$)$ in a dose dependent manner at concentrations $\geq 0.78: 2.34 \mu \mathrm{g} / \mathrm{mL}$. However, carvedilol and celecoxib were non mutagenic against either mutant strain (TA 100 and TA 98) and combinations have also shown mild to moderate mutagenic potential. Nevertheless, upon addition of metabolic activation enzyme, concentration $<12.5: 37.5 \mu \mathrm{g} /$ plate exhibited significant $(\mathrm{P}<0.05)$ mutagenicity against both tester strains. In conclusion, this study provides additional genotoxicity and mutagenicity data that could be used in considering options for formulating regimens with reduced mutagenic potential.
\end{abstract}

Keywords; Carvedilol. Celecoxib. Mutagenicity. Genotoxicity. Cytotoxicity.

\section{INTRODUCTION}

Hypertension affects seventy six million people in the United States and 1 billion worldwide each year and projection depicts that by 2030 prevalence of hypertension will increase by $7.2 \%$ from estimates (Mills et al., 2016). Essential hypertension, or hypertension of obscure cause, represents beyond $90 \%$ of instances of hypertension. It tends to cluster in families and represents a collection of genetically based diseases or syndromes with several resultant inherited biochemical abnormalities (Renna et al., 2013). The resulting phenotypes can be modulated by various environmental factors, thereby altering the severity of blood pressure

\footnotetext{
*Correspondence: A. Attiq*. Drug and Herbal Research Center, Faculty of Pharmacy, University Kebangsaan Malaysia, Jalan Raja Muda Abdul Aziz, Kuala Lumpur, 50300, Malaysia. E-mail: aliattiqbutt@gmail.com
}

elevation and the timing of hypertension onset. Numerous pathophysiologic factors have been implicated in the genesis of essential hypertension, obesity and diabetes among the most common ones. Hypertension has been considered as a silent killer amongst all other ailments due to its diminished signs and symptoms. Consequently, if hypertension remains undiagnosed (Blood Pressure [BP] failing to be checked previously), known to the patient, however, left untreated, and known hypertensive patients with low adherence to both antihypertensive drugs and lifestyle modification can invariably lead to chronic kidney disease (CKD) (Mancia et al., 2009). Beta-Blockers are antihypertensive medication and, together with diuretics, have been the foundation of studies signifying their advantages on cardiovascular morbidity and mortality. Carvedilol is a vasodilating non-cardio specific third-generation $\beta$-blocker, unlike conventional beta blockers carvedilol has negative hemodynamic and 
metabolic effects (Fergus, Connell, Ferdinand, 2015). Due to these pleotropic activities carvedilol is becoming a preferred therapeutic option among medical practitioners. Invariably, uncontrolled hypertension often comes with co-morbidities. Musculoskeletal pain, associated with the inflammatory diseases has the high prevalence in hypertensive patients (Panoulas et al., 2008). Studies have shown that vascular inflammation is one of the leading cause for the development of hypertension and arteriosclerosis (Gerli et al., 2005; Savoia, Schiffrin, 2006). Henceforth, inflammation and hypertension go hand in hand. In this scenario, celecoxib, an over the counter non-steroidal anti-inflammatory drug (NSAID) with mark anti-inflammatory and analgesic properties, has become physician's drug of choice. It is approved for the treatment of rheumatoid arthritis, osteoarthritis, and acute pain (van Walsem et al., 2015). The antiinflammatory and analgesic properties of celecoxib result from inhibition of prostaglandin (PG) synthesis by selective inhibition of $\mathrm{PG} \mathrm{G} / \mathrm{H}$ synthase- 2 usually stated as cyclooxygenase 2 (COX-2) (Tarr, Reuter, 2015). The use of carvedilol and celecoxib combination has been very common in clinical settings and regardless of their order of administration such drugs can exhibit drug interaction. Moreover, it is impossible to predict the outcome of these interactions of the drugs, based on the individual effect, in their combinations. Established on the fact that duration of treatment of hypertension may last for decades and prolong usage of multiple drug regimens may induce significant pathophysiological changes at cellular level. The overriding goal of this effort is to provide additional genotoxicity and mutagenicity data that could be used in considering options for formulating prophylaxis/treatment regimens with reduced mutagenic potential and thus reduced long-term risk for cancer.

\section{MATERIAL AND METHODS}

Shodhana Laboratories Private Limited, Hyderabad India, kindly donated analytical grade samples of carvedilol and celecoxib. Dulbecco's modified eagle medium (DMEM) (Cat no. 12120014, Caisson Lab, USA); Fetal bovine serum (Cat no. S181H-500, Bio-west, USA); MTT [3-(4,5-dimethylthiazolyl-2)-2,5-diphenyltetrazolium bromide](Cat. no. 29893-1, Sigma-Aldrich, USA); dimethylsulfoxide (DMSO)(Cat. no. 0000179027 , Paneac QuimicaSAU, Spain); metabolic activation system (S9)(Cat. no. 505189D, EBPI environmental Biodetection products Inc., Canada); Salmonella typhi TA100 and TA98 tester stains (Environmental Bio-detection Products Incorporation (EBPI), Canada); Histopaque /
Lymphocyte Separating Medium (Cat no: S11230L0560, Biowest, France, Roswell Park Memorial Institute Medium(RPMI-1640)(Cat no;0214003, Caisson, USA); Low melting point agarose (LMPA)(Cat. no. 10011055 , Fine chemicals HT Company, UK); Normal melting point agarose(NMPA)(Cat no. 42083100, Fine chemicals HT Company, UK);Triton-X100 (Cat no. 242639, Panreeac, Spain); sodium hydroxide (Cat. no. 58641, Batch no. 77620, Scharlau, Germany); sodium chloride (Cat. NOCHB3266, Riedel-de-Haen, Germany); hydrochloric acid (Cat. no. AB61, Batch no. 02110133, Labscan, Ireland); Nutrient broth (Cat. No. AM5077, LOT no. 1101, UK); purified Ager (Cat. no. 306200012, Duplus, UK); hydrochloric acid (HCl) (Batch no. 0240133, Cat. no. AB61, Lab scan, Ireland); ethidium bromide (LOT no. 1004DU23819; Cat. no. 1239-45-8, Bio basic Inc., Canada); histidine (Cat. no. 101937, MP biomedical, France); biotin (Cat. no, 20284101, Daejung Chem Ltd, Korea); sodium azide (Lot no. V11052400, Cat. No. 41900064-1, Bioworld, USA); phosphate buffer (Lot no. 2431B77, Cat. no. 41620016-1, Bioworld, USA); potasium dihydrogen phosphate (Lot. no. PO02570500, Batch no. 11650701), Methanol (Lot no. 2839070L, Analar (BDH) UK); Trisbase (Cat. no. 240202362, Lot. no. 26089, Bioworld, USA) and EDTA (Lot. no. 62720, RDH Lab, USA) were provided by the department of Pharmacology and Toxicology, University of Veterinary and Animal Sciences, Lahore, Pakistan.

\section{Experimental design}

Toxic concentrations tested in this experiment were carefully selected keeping all the following parameters under consideration; 1) maximum repeatable dose (MRD) which provides a preview of the toxicology of new and old drug combinations; 2) Toxicokinetic (TK) range which gives a formal data of drug action at peak plasma concentrations of unknown drugs, and 3) Dose incrimination (two fold increase) process to evaluate acute, sub-chronic and chronic drug toxicity. Finally relevance to effective dose of Carvedilol $\left(\mathrm{ED}_{50}=0.04 \mu \mathrm{g} / \mathrm{mL}\right)($ Cheng et al., 2007) and celecoxib (ED50 $=1.14 \mu \mathrm{g} / \mathrm{mL}$ ) (Ouellet, Riendeau, Percival, 2001) and clinical indications were also taken under consideration (Buckley, Dorato, 2009). Hence, selective range of cumulative dilutions of carvedilol $(200 \mu \mathrm{g} / \mathrm{mL}, 150 \mu \mathrm{g} / \mathrm{mL}, 100 \mu \mathrm{g} / \mathrm{mL}, 50 \mu \mathrm{g} /$ $\mathrm{mL}, 25 \mu \mathrm{g} / \mathrm{mL}, 12.5 \mu \mathrm{g} / \mathrm{mL}, 6.25 \mu \mathrm{g} / \mathrm{mL}, 3.12 \mu \mathrm{g} / \mathrm{mL}$, $1.56 \mu \mathrm{g} / \mathrm{mL}, 0.78 \mu \mathrm{g} / \mathrm{mL})$ and celecoxib $(600 \mu \mathrm{g} / \mathrm{mL}$, $450 \mu \mathrm{g} / \mathrm{mL}, 300 \mu \mathrm{g} / \mathrm{mL}, 150 \mu \mathrm{g} / \mathrm{mL}, 75 \mu \mathrm{g} / \mathrm{mL}, 37.5 \mu \mathrm{g} /$ $\mathrm{mL}, 18.75 \mu \mathrm{g} / \mathrm{mL}, 9.34 \mu \mathrm{g} / \mathrm{mL}, 4.68 \mu \mathrm{g} / \mathrm{mL}, 2.34 \mu \mathrm{g} / \mathrm{mL}$ ) were evaluated, alone and in combinations of increasing proportion of both drugs. 


\section{Cytotoxicity assay (MTT assay)}

\section{Treatment of cell line}

DMEM supplemented with $20 \%$ fetal bovine serum was used to cultivate adherent Vero cell lines. Adherent cells were treated with each test dilutions individually and incubated for $48 \mathrm{~h}$ in $5 \% \mathrm{CO}_{2}, 95 \%$ air at $37^{\circ} \mathrm{C}$. After $48 \mathrm{~h}$, viability of Vero cells was measured by adding $20 \mu \mathrm{L}$ MTT dye solution $(50 \mathrm{mg} / 10 \mathrm{~mL})$ in each well and cells were further incubated for $3 \mathrm{~h}$ (Ohno, Abe, 1991). Once this incubation time was completed, $100 \mu \mathrm{L}$ of $10 \% \mathrm{DMSO}$ were added to the 96 wells. The numbers of the viable cells in each well was proportional to the intensity of the absorbance of light, which was then read in an ELISA plate reader at $570 \mathrm{~nm}($ Mosmann, 1983). Moreover, cell survival percentage values were used to evaluate the $\mathrm{IC}_{50}$ values of carvedilol, celecoxib and their combinations using prism graphpad 5.

Cell Survival Percentage $(\mathrm{CSP})=\frac{\left(\begin{array}{c}\text { Mean optical density } \\ \text { of test chemical }\end{array}\right)-\left(\begin{array}{c}\text { Mean optical density } \\ \text { of negative control }\end{array}\right)}{\text { Mean optical density of positive control }} \times 100$

\section{Genotoxicity (comet assay)}

Lymphocytes separating media was used for the extraction of peripheral mononuclear cells (PMN). After incubating the PMNs with drug concentrations, group of single cells were transferred on frosted cavity slides. These pits were filled with Normal melting ager
(NMA), $0.6 \%$ agar layer on top of a $0.6 \%$ agar base layer, a third top layer comprising of $0.6 \%$ low liquefying point agar. Slides were placed in lysis solution $(2.5 \mathrm{M}$ $\mathrm{NaCl}, 100 \mathrm{mM}$ EDTA, $10 \mathrm{mM}$ Tris, 1\%, 10\% DMSO and $1 \%$ Triton) for $18-24 \mathrm{~h}$ and later were submersed in electrophoresis buffer (0.3 M NaOH, 1 mM EDTA) for $40 \mathrm{~min}$, this allowed the DNA strand to break and unwind. Later, the power supply was adjusted at 24 volts and $300 \mathrm{~mA}$. Slides were electrophoresed for 30 min. Slides were taken out after 30 minutes and placed on a dry surface. These slides were then neutralized and stained with ethidium bromide $(10 \mathrm{mg} / 50 \mathrm{~mL})$. DNA damage was determined by measuring the DNA comet length from the core. Quantitation was carried out on a fluorescent image analysis system that compared the overall length of intact nuclei versus damaged nuclei with a comet tail. The comets were observed under fluorescent microscope (BX41, product no. 5M16529 TF, Olympus, Japan) and pictures were taken with digital microscope camera (DP70, product no. 6B05172, Olympus, Japan) and analyzed through Image J software for percentage fragmentation. Finally comets are characterize in four different classes (Singh et al., 1988).

\section{Class $0=$ Undamaged Nuclei}

Class 1 = Tail length $\leq$ Undamaged Nuclei head diameter Class 2 = Tail length $>$ Undamaged Nuclei head diameter but $<2 \mathrm{X}$ Nuclei head diameter

Class $3=$ Tail length $>2$ X Undamaged Nuclei head diameter.

TABLE I - Cell viability of Vero cell line was measured in term of optical density using MTT assay after treatment with various doses of Carvedilol, Celecoxib and their combinations with respective controls for 48 hours.

\begin{tabular}{cccccccc}
\hline \multicolumn{2}{c}{ Carvedilol } & \multicolumn{2}{c}{ Celecoxib } & \multicolumn{2}{c}{ Carvedilol: Celecoxib } & \multicolumn{2}{c}{ Controls } \\
\hline Conc. $^{\text {a }}$ & OD $^{\mathbf{b}} \pm$ S.D & Conc. & OD \pm S.D & Conc. & OD \pm S.D & Conc. & OD \pm S.D \\
\hline 0.78 & $0.89 \pm 0.06$ & 2.34 & $0.86 \pm 0.01$ & $0.78: 2.34$ & $0.79 \pm 0.02$ & Positive & $0.06 \pm 0.08$ \\
1.56 & $0.74 \pm 0.05$ & 4.68 & $0.83 \pm 0.02$ & $1.56: 4.68$ & $0.77 \pm 0.08$ & Control (Blank & wells) \\
3.12 & $0.69 \pm 0.07$ & 9.37 & $0.77 \pm 0.02$ & $3.12: 9.37$ & $0.74 \pm 0.11$ & & \\
6.25 & $0.64 \pm 0.01$ & 18.75 & $0.70 \pm 0.03$ & $6.25: 18.75$ & $0.65 \pm 0.01^{*}$ & & $0.97 \pm 0.07$ \\
\hline 12.5 & $0.59 \pm 0.01$ & 37.5 & $0.67 \pm 0.02$ & $12.5: 37.5$ & $0.56 \pm 0.07^{*}$ & Negative & \\
25 & $0.49 \pm .001^{*}$ & 75 & $0.56 \pm .002$ & $25: 75$ & $0.49 \pm 0.09^{*}$ & Control & $($ DMEM) \\
50 & $0.43 \pm 0.04^{*}$ & 150 & $0.45 \pm 0.03^{*}$ & $50: 150$ & $0.41 \pm 0.05^{* *}$ & & \\
100 & $0.35 \pm 0.03^{*}$ & 300 & $0.39 \pm 0.01^{* *}$ & $100: 300$ & $0.38 \pm 0.03^{* * *}$ & & \\
150 & $0.33 \pm 0.02^{* *}$ & 450 & $0.35 \pm 0.02^{* * *}$ & $150: 450$ & $0.34 \pm 0.03^{* * *}$ & & \\
200 & $0.29 \pm 0.06^{* *}$ & 600 & $0.32 \pm 0.02^{* * *}$ & $200: 600$ & $0.29 \pm 0.01 * * *$ & & \\
\hline
\end{tabular}

${ }^{\mathrm{c}}$ Concentration $=\mu \mathrm{g} / \mathrm{ml},{ }^{\mathrm{b}} \mathrm{OD}=$ Mean optical density of the cells against the control exposed to that concentration in terms of mean \pm standard deviation. Statistical significance was analyzed using the two-way ANOVA followed by Post Hoc Duncan, $* \mathrm{P}<0.05$, $* * \mathrm{P}<0.01,{ }^{*} * \mathrm{P}<0.001$ vs positive control, $* \mathrm{P}<0.05, * * \mathrm{P}<0.01, * * * \mathrm{P}<0.001$ vs positive control. 
Damage index $=$ No. Of cells in Class $1+(2 \times$ No. of the cells in Class 2$)+(3 \times$ No. of cells in Class 3$)$

\section{Mutagenicity (AMES assay)}

Pre-incubation assay was utilized for mutagenicity evaluation of Carvedilol and Celecoxib. Mutagenic potential of carvedilol, celecoxib and combinations were evaluated on two Salmonella typhi tester strains TA100 and TA98. Both tester strains TA 98 and TA 100 were inoculated in a fresh sterilized nutrient broth for $15-18 \mathrm{~h}$ prior to the assay performance. The Bacterial number was balanced at 0.5 mcfarland (mcf) by adjusting the optical density using spectrophotometer. Each drug dilution was exposed with $0.1 \mathrm{~mL}$ of bacterial suspension $(2 \mathrm{x}$ $10^{8}$ bacteria), incubated for 20 minutes and then spread over GM ager plates. Plates were then incubated for 48 $\mathrm{h}$ at $37^{\circ} \mathrm{C}$. Likewise, the procedure was replicated with metabolic activation system (S9 mix) by adding $0.5 \mathrm{~mL}$ of the S9 fraction in each drug dilution. Finally, histidine independent revertant colonies were counted manually and results were calculated in term of mutagenic index by the following formula (Mortelmans, Zeiger, 2000)

\section{Mutagenic Index}

$$
\frac{\left(\begin{array}{c}
\text { Number of revertant colonies per } \\
\text { plate with test chemical dose }
\end{array}\right)}{\left(\begin{array}{c}
\text { Number of natural revertant } \\
\text { colonies of negative control plate }
\end{array}\right)}
$$

Negative Control $\times 2=$ Possible Mutagen, Negative Control $\times 3=$ Significant Mutagen, Negative Control $\times 4$ and above $=$ Highly Significant Mutagen

\section{Statistical analysis}

The results were analyzed by Statistical Package Of Social Sciences (SPSS for windows version 16, SPSS Inc., Chicago IL USA). The results were explained in terms of means $\pm \mathrm{SD}$. The results were considered significant if the $(p<0.05),(p<0.01)$ and $(p<0.001)$. Analysis of variance (TWO WAYANOVA) along with Post Hoc Duncan test was applied to the data to find out the relation between the DNA damage index, Cell survival percentage and the relationship between the means of mutagenic index and dose response among the treatments (Aghbali et al., 2014).

\section{RESULTS}

\section{MTT assay}

After incubating the cells for $48 \mathrm{hrs}$ with test samples, results were presented in form of cell survival percentage (CSP) (Figure 1). All three treatments significantly $(\mathrm{P}<0.05)$ inhibited the proliferation of Vero cell in a concentration-dependent manner. Recorded $\mathrm{IC}_{50}$ for carvedilol and celecoxib were $20.4 \pm 0.2 \mu \mathrm{g} / \mathrm{mL}$ and $84.7 \pm 0.3 \mu \mathrm{g} / \mathrm{mL}$, respectively, whereas their combinations have shown increase pattern of cytotoxicity with a combine $\mathrm{IC}_{50}$ of 13.7:47.8 $\mu \mathrm{g} / \mathrm{mL}$. The effects of combinations were more cytotoxic as compared to individual drugs (Figure 1).

\section{Comet assay}

The genotoxic potentials of carvedilol, and celecoxib were evaluated on peripheral mononuclear cells and extent of the DNA damage was expressed in terms of percentage fragmentation of DNA(Table II). Carvedilol has exhibited
(A)

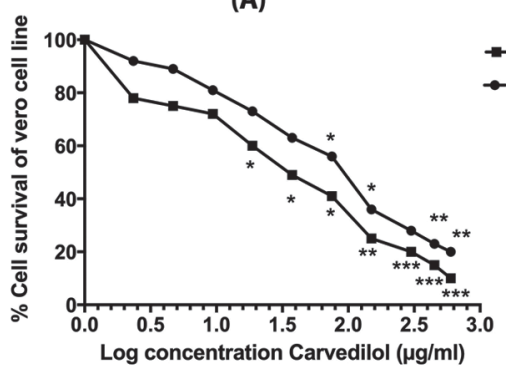

(B)

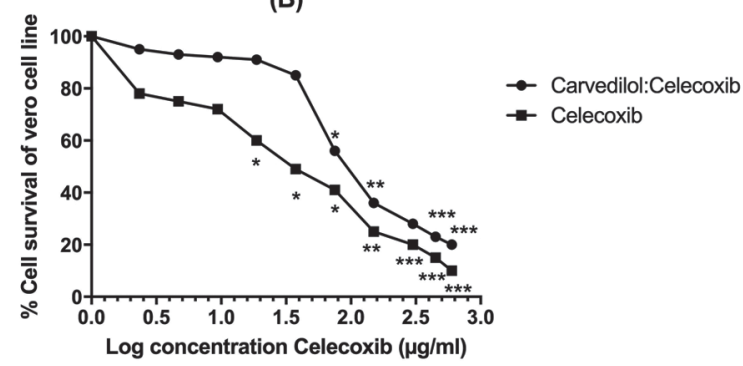

FIGURE 1 - Concentration dependent response in cell survival percentage (CSP) of Vero cells ( 2 x 104 cells/0.1 mL/well) assessed by MTT assay after 48 hours of incubation with test chemicals, (A) comparison of CSP after carvedilol and combine concentration of carvedilol and celecoxib (B) comparison of CSP after celecoxib and combine concentration of carvedilol and celecoxib. The graph shows that anti-proliferative effect of combine concentration carvedilol:celecoxib) was significant at lower level as compare to both carvedilol and celecoxib alone. Each value represent of mean three replicates $(n=3)$. The asterisks indicate significant difference at three levels $\left({ }^{*} \mathrm{p}<0.05,{ }^{*} \mathrm{p}<0.01,{ }^{* * *} \mathrm{p}<0.001\right)$ between cells cultured after 48 hours of treatments. 

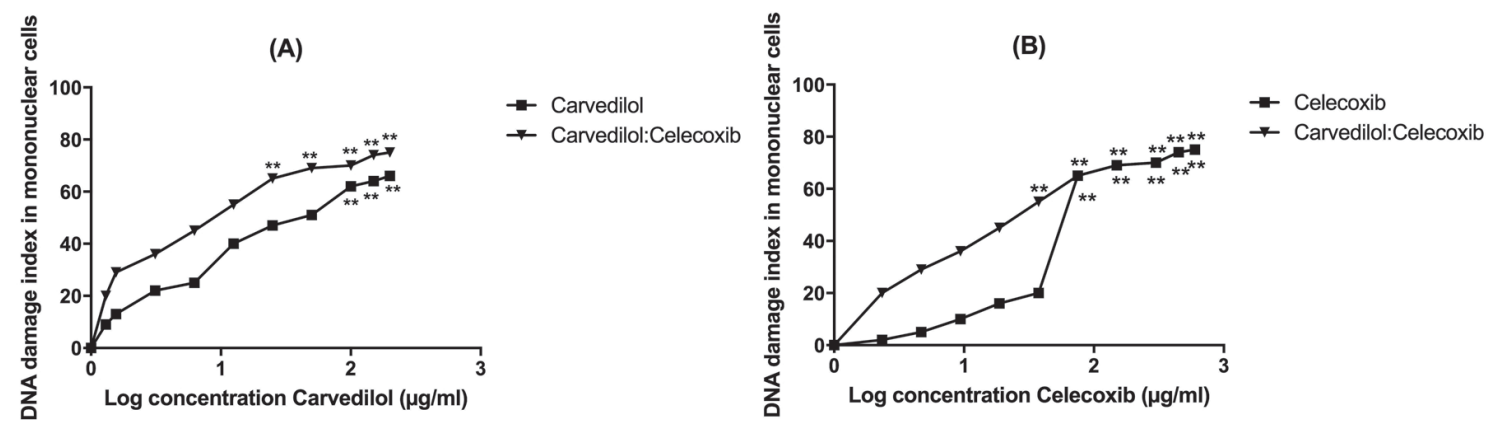

FIGURE 2 - DNA damage index of carvedilol, celecoxib and their combination (carvedilol:celecoxib) in peripheral blood mononuclear cells (PBMCs) measured by Single Cell Gel Electrophoresis, (A) comparison of DNA damage index after carvedilol and combination (B) comparison of DNA damage index after celecoxib and combination. The graphs shows that the DNA damage induced after treatment with carvedilol and combine concentrations were significant. Nevertheless DNA damages induced by $>75$ $\mu \mathrm{g} / \mathrm{mL}$ of celecoxib were also genotoxic when used alone and combinations. Each Value represent of mean three replicates $(\mathrm{n}=3)$. The asterisk indicate significant difference at $* * \mathrm{p}<0.01$ between cells.

maximum DNA damage at $200 \mu \mathrm{g} / \mathrm{mL}$ leading to Class 3 tail formation (Figure 3). Moreover, at lowest tested concentration of Carvedilol $(0.78 \mu \mathrm{g} / \mathrm{mL})$, head to tail ratio was approximately $2: 1$ with $10 \%$ DNA fragmentation and class 1 damage (Figure 3). Whereas for celecoxib damage was only observed at concentrations $\geq 75 \mu \mathrm{g} / \mathrm{mL}$ with class 3 damage and 100\% fragmentation (Figure 3, Table II). Furthermore, maximum tail length formation was observed with carvedilol and celecoixb combinations, where an average of class 3 damage with as average of $30 \%$ fragmentation was recorded at concentration range of 0.78:2.34 $\mu \mathrm{g} / \mathrm{mL}$ to $200: 600 \mu \mathrm{g} / \mathrm{mL}$ (Table II), suggesting that combination of carvedilol and celecoxib has exhibited synergetic genotoxic potential (Figure 3).

\section{AMES assay}

Mutagenic potential of Carvedilol, Celecoxib and combinations were evaluated on two Salmonella typhi tester strains TA100 and TA98. After incubating the mutant strains for $48 \mathrm{hrs}$ with the test concentrations, results were presented in terms of number of revertant colonies/plate and mutagenic index as shown in Table III. As expected, carvedilol and celecoxib failed to produce histidine independent revertant colonies in both TA98 and TA 100 . However, mild to moderate mutagenicity was observed when combination of Carvedilol and Celecoxib were incubated with mutant strain and metabolic activation system was added to mimic the in vivo condition. Upon addition of metabolic activation system histidine independent revertent colonies were observed at concentrations $\geq 3.12: 9.38 \mu \mathrm{g} /$ plate, with mutagenic index of $\geq 2.0$ (Table III). On the other hand, the combinations of both drugs were not mutagenic at therapeutic concentrations of $0.04 \mu \mathrm{g} / \mathrm{mL}$ and $1.14 \mu \mathrm{g} / \mathrm{mL}$ of carvedilol and celecoxib, respectively (Table III).

\section{DISCUSSION}

The superior therapeutic efficacy of carvedilol in lowering blood pressure and of celecoxib on inflammatory pains motivated physician to prescribe this combination for multiple years and in some cases for entire life. The possible cytotoxic, genotoxic and mutagenic effect of combination of carvedilol and celecoxib were evaluated in this study using well-established MTT, Ames and SCGE in vitro assay. Carvedilol has shown promising results in several anti-proliferative studies. Proposed mechanisms includes (a) $\mathrm{Ca} 2+$ release from the endoplasmic reticulum which leads to apoptosis (Cheng et al., 2007) and (b) direct mitochondrial damage causing cells arrest at $\mathrm{G} 0 / \mathrm{G} 1$ phase (Erguven et al., 2010). In this experiment, carvedilol has shown substantial cytotoxicity at concentrations above $12.5 \mu \mathrm{g} / \mathrm{mL}$, and $\mathrm{IC}_{50} 20.4 \pm 0.22 \mu \mathrm{g} / \mathrm{mL}$ (Figure 1). The following concentrations of carvedilol; $25 \mu \mathrm{g} / \mathrm{mL}, 50$ $\mu \mathrm{g} / \mathrm{mL}, 100 \mathrm{~g} / \mathrm{mL}, 150 \mu \mathrm{g} / \mathrm{mL}$ and $200 \mu \mathrm{g} / \mathrm{mL}$ have statistically significant difference in CSP as compared to control (Figure 1), whereas celecoxib results suggested that concentrations $>75 \mu \mathrm{g} / \mathrm{mL}$ are potential cytotoxic for given cell line with $\mathrm{IC}_{50} 84.7 \pm 0.34 \mu \mathrm{g} / \mathrm{mL}$ (Table I). Literature suggests that its COX-2 growth-inhibitory and apoptosis-stimulatory potential is primarily responsible for its noticeable anti-proliferative activity (Zuo et al., 2015). Furthermore, test concentrations of combinations produced synergistic cytotoxic potential and cell viability of Vero cell line plunged abruptly upon exposure. Seven combined concentrations $(6.25: 18.75 \mu \mathrm{g} / \mathrm{mL}, 12.5: 37.5$ $\mu \mathrm{g} / \mathrm{mL}, 25: 75 \mu \mathrm{g} / \mathrm{mL}, 50: 150 \mu \mathrm{g} / \mathrm{mL}, 100: 300 \mu \mathrm{g} / \mathrm{mL}$, 
TABLE II - Percentage fragmentations of DNAs in the peripheral blood mononuclear cells (PBMCs) measured by single cell gel electrophoresis (comet assay) after $3 \mathrm{~h}$ incubation with various concentrations of Carvedilol, Celecoxib and their combination compared to respective controls.

\begin{tabular}{|c|c|c|c|c|}
\hline Treatment & $\begin{array}{c}\text { Concentration } \\
(\mu \mathrm{g} / \mathrm{ml}) \\
\end{array}$ & $\begin{array}{l}\text { Mean DNA Head } \\
\text { Length }(\mu \mathrm{m})\end{array}$ & $\begin{array}{c}\text { Mean Tail length } \\
(\mu \mathrm{m})\end{array}$ & $\%$ Fragmentation \\
\hline \multirow{10}{*}{ Carvedilol } & 200 & $1.97 \pm 0.65$ & $8.46 \pm 2.54$ & $100 * *$ \\
\hline & 150 & $1.96 \pm 0.80$ & $8.09 \pm 2.41$ & $92 * *$ \\
\hline & 100 & $2.15 \pm 0.16$ & $7.36 \pm 2.10$ & $92 * *$ \\
\hline & 50 & $2.16 \pm 0.98$ & $6.21 \pm 2.41$ & $84 * *$ \\
\hline & 25 & $2.20 \pm 0.55$ & $5.00 \pm 1.95$ & 76 \\
\hline & 12.6 & $2.41 \pm 0.31$ & $4.68 \pm 2.56$ & 68 \\
\hline & 6.25 & $3.51 \pm 0.40$ & $3.418 \pm 1.48$ & 60 \\
\hline & 3.125 & $3.57 \pm 1.48$ & $2.59 \pm 0.57$ & 52 \\
\hline & 1.56 & $3.76 \pm 1.91$ & $2.09 \pm 1.59$ & 48 \\
\hline & 0.78 & $3.99 \pm 1.06$ & $2.33 \pm 1.18$ & 10 \\
\hline \multirow{10}{*}{ Celecoxib } & 600 & $2.59 \pm 0.392$ & $10.81 \pm 0.701$ & $100 * *$ \\
\hline & 450 & $2.66 \pm 0.410$ & $10.07 \pm 0.805$ & $100 * *$ \\
\hline & 300 & $3.06 \pm 0.1903$ & $7.03 \pm 2.134$ & $100 * *$ \\
\hline & 150 & $4.34 \pm 01.468$ & $6.21 \pm 2.411$ & $100 * *$ \\
\hline & 75 & $2.20 \pm 0.559$ & $4.36 \pm 0.662$ & $92 * *$ \\
\hline & 37.5 & $4.15 \pm 1.601$ & $0.482 \pm 1.279$ & 36 \\
\hline & 18.75 & $4.16 \pm 0.573$ & $0.489 \pm 1.125$ & 36 \\
\hline & 9.375 & $4.50 \pm 1.125$ & $0 \pm 0.00$ & 10 \\
\hline & 4.69 & $5.22 \pm 0.941$ & $0 \pm 0.00$ & 9 \\
\hline & 2.34 & $5.76 \pm 1.063$ & $0 \pm 0.00$ & 5 \\
\hline \multirow{10}{*}{ Carvedilol:Celecoxib } & 200:600 & $1.68 \pm 0.81$ & $9.46 \pm 1.49$ & $100 * *$ \\
\hline & $150: 450$ & $1.77 \pm 1.49$ & $8.28 \pm 0.94$ & $100 * *$ \\
\hline & $100: 300$ & $2.01 \pm 0.53$ & $7.70 \pm 0.66$ & $100 * *$ \\
\hline & $50: 150$ & $2.59 \pm 0.67$ & $6.06 \pm 1.52$ & $100 * *$ \\
\hline & $25: 75$ & $3.21 \pm 0.68$ & $4.92 \pm 1.58$ & $92 * *$ \\
\hline & $12.5: 37.5$ & $3.33 \pm 1.12$ & $4.51 \pm 0.95$ & $88 * *$ \\
\hline & $6.25: 18.75$ & $3.42 \pm 0.63$ & $4.07 \pm 1.12$ & 76 \\
\hline & $3.125: 9.375$ & $4.50 \pm 1.12$ & $3.78 \pm 1.31$ & 64 \\
\hline & $1.56: 4.69$ & $5.22 \pm 0.94$ & $3.27 \pm 1.12$ & 56 \\
\hline & $0.78: 2.34$ & $5.76 \pm 1.06$ & $3.11 \pm 0.56$ & 36 \\
\hline Positive Control & $20 \%$ DMSO & $0.78 \pm 0.011$ & $13.3 \pm 0.333$ & 78 \\
\hline Negative Control & RPMI Medium & $5.78 \pm 0.166$ & $0.37 \pm 0.002$ & 8 \\
\hline
\end{tabular}

150:450 $\mu \mathrm{g} / \mathrm{mL}, 200: 600 \mu \mathrm{g} / \mathrm{mL}$ ) showed statistically significant difference in CSP as compare to control cells (Table I) exhibiting an increase cytotoxicity of combination. Previously, both drugs have been analyzed in combination with known anticancer drugs. Carvedilol has shown greater cytotoxicity with imatinib against brain tumor (Erguven et al., 2010) and with doxorubicin against breast cancer (Jonsson et al., 1999). Data suggested that similar attribute has been associated with Celecoxib as well, combination of Cisplatin and Celecoxib has enhanced therapeutic response against chemotherapy resistant gastric cancer (Xu, Shen, Lv et al., 2016), with Imatinib, Celecoxib has shown superior efficacy against Chronic myelogenous leukemia (CML) by suppressing 


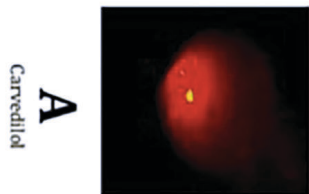

$200 \mu \mathrm{g} / \mathrm{ml}$

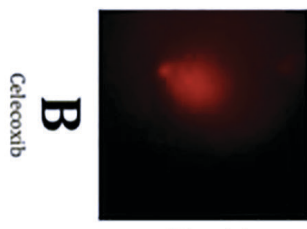

$600 \mu \mathrm{g} / \mathrm{ml}$

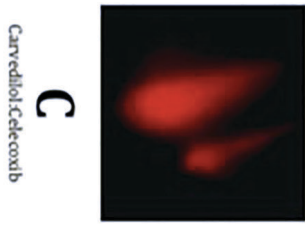

$200: 600 \mu \mathrm{g} / \mathrm{ml}$

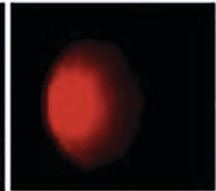

$150 \mu \mathrm{g} / \mathrm{ml}$

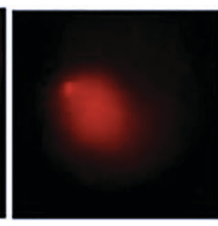

$450 \mu \mathrm{g} / \mathrm{ml}$

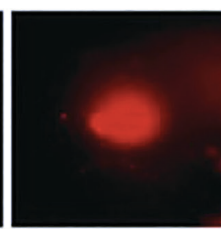

$150: 450 \mu \mathrm{g} / \mathrm{ml}$

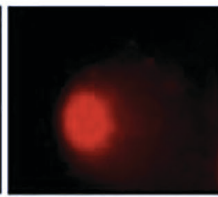

$0.72 \mu \mathrm{g} / \mathrm{ml}$

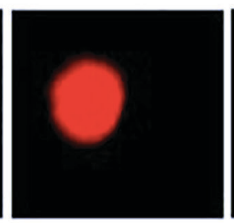

$2.34 \mu \mathrm{g} / \mathrm{ml}$

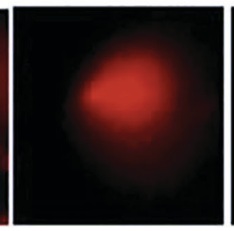

$0.72: 200 \mu \mathrm{g} / \mathrm{ml}$

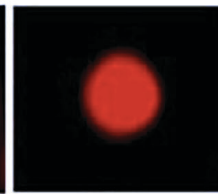

Nogative

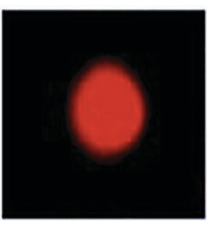

Negative

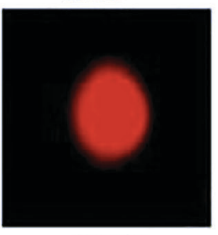

Negative
Control

FIGURE 3 - Representative comets with increasing concentrations of three treatment groups. [A] shows the comets protrude by carvedilol $200 \mu \mathrm{g} / \mathrm{mL}, 150 \mu \mathrm{g} / \mathrm{mL}, 0.72 \mu \mathrm{g} / \mathrm{mL}$ and negative control (Class 0 Damage) [B] Shows the comets protrude by celecoxib $600 \mu \mathrm{g} / \mathrm{mL}, 450 \mu \mathrm{g} / \mathrm{mL}$ and $2.34 \mu \mathrm{g} / \mathrm{mL}$ and negative control [C] Shows the comets protrude by combine concentrations of carvedilol and celecoxib 200:600 $\mu \mathrm{g} / \mathrm{mL}, 150: 450 \mu \mathrm{g} / \mathrm{mL}, 0.72: 2.34 \mu \mathrm{g} / \mathrm{mL}$ and negative control (Class 0 Damage) respectively.

TABLE 3. Shows the mutagenic potential in terms of mean number of revertant colonies/plate, standard deviation (SD) and mutagenic index (M.I) recorded against salmonella typhi TA-98 and TA-100, in the presence (+S9) and absence (-S9) of metabolic activation system.

\begin{tabular}{|c|c|c|c|c|c|}
\hline \multirow{3}{*}{ Treatment $\mu g /$ Plate } & & \multicolumn{4}{|c|}{ Mean Number of revertant $(\mathrm{M} \pm \mathrm{SD}) /$ plate and $\mathrm{MI}$ in parenthesis } \\
\hline & & \multicolumn{2}{|c|}{ TA98 } & \multicolumn{2}{|l|}{ TA 100} \\
\hline & & -S9 & $+\mathbf{S 9}$ & -S9 & $+\mathbf{S 9}$ \\
\hline \multirow{5}{*}{ Carvedilol } & 0.78 & $54 \pm 2(0.83)$ & $79 \pm 3(0.89)$ & $89 \pm 3(0.90)$ & $103 \pm 5(0.88)$ \\
\hline & 1.56 & $63 \pm 4(0.96)$ & $106 \pm 6(1.21)$ & $99 \pm 4(1.10)$ & $110 \pm 6(0.94)$ \\
\hline & 3.12 & $69 \pm 7(1.06)$ & $124 \pm 3(1.41)$ & $104 \pm 3(1.06)$ & $131 \pm 4(1.11)$ \\
\hline & 6.26 & $73 \pm 3(1.12)$ & $134 \pm 7(1.53)$ & $130 \pm 5(1.33)$ & $177 \pm 8(1.50)$ \\
\hline & 12.5 & $88 \pm 5(1.36)$ & $149 \pm 4(1.70)$ & $154 \pm 6(1.57)$ & $6221 \pm 3(1.88)$ \\
\hline \multirow{5}{*}{ Celecoxib } & 2.34 & $52 \pm 3(0.81)$ & $81 \pm 3(0.92)$ & $81 \pm 2(0.82)$ & $98 \pm 5(0.83)$ \\
\hline & 4.69 & $60 \pm 2(0.91)$ & $88 \pm 1(1)$ & $93 \pm 3(0.94)$ & $114 \pm 4(0.96)$ \\
\hline & 9.37 & $63 \pm 6(0.96)$ & $95 \pm 7(1.07)$ & $101 \pm 7(1.03)$ & $141 \pm 8(1.19)$ \\
\hline & 18.75 & $79 \pm 1(1.21)$ & $144 \pm 9(1.64)$ & $156 \pm 6(1.59)$ & $198 \pm 5(1.67)$ \\
\hline & 37.5 & $93 \pm 8(1.43)$ & $156 \pm 5(1.77)$ & $169 \pm 8(1.72)$ & $216 \pm 11(1.83)$ \\
\hline \multirow{7}{*}{ Carvedilol:Celecoxib } & $0.78: 2.34$ & $88 \pm 2(1.35)$ & $146 \pm 3(1.66)$ & $155 \pm 5(1.58)$ & $205 \pm 7(1.74)$ \\
\hline & $1.56: 4.68$ & $100 \pm 4(1.55)$ & $157 \pm 4(1.79)$ & $175 \pm 4(1.78)$ & $219 \pm 4(1.86)$ \\
\hline & 3.12 .9 .73 & $115 \pm 7(1.77)$ & $172 \pm 8(1.96)^{*}$ & $189 \pm 8(1.92)^{*}$ & $244 \pm 8(2.07)^{*}$ \\
\hline & $6.25: 18.75$ & $145 \pm 4(2.24)^{* *}$ & $218 \pm 4(2.48)^{* *}$ & $213 \pm 5(2.17)^{*}$ & $333 \pm 6(2.82)^{*}$ \\
\hline & $12.5: 37.5$ & $166 \pm 7(2.55)^{* *}$ & $248 \pm 6(2.82)^{* *}$ & $268 \pm 6(2.73)^{* *}$ & $353 \pm 9(2.99)^{* * *}$ \\
\hline & Positive Control & $540 \pm 65^{b}$ & $1220 \pm 70^{c}$ & $756 \pm 53^{b}$ & $1540 \pm 88^{\mathrm{c}}$ \\
\hline & Negative Control & $65 \pm 4^{a}$ & $88 \pm 5^{\mathrm{a}}$ & $98 \pm 4^{a}$ & $118 \pm 6^{\mathrm{a}}$ \\
\hline
\end{tabular}

$\mathrm{M} \pm \mathrm{SD}=$ mean and standard deviation; $\mathrm{MI}=$ mutagenic index; ${ }^{\mathrm{a} N e g a t i v e ~ c o n t r o l: ~ D i m e t h y l s u l f o x i d e ~(50 \mu 1 / p l a t e) ; ~}{ }^{\mathrm{b}}$ Positive control

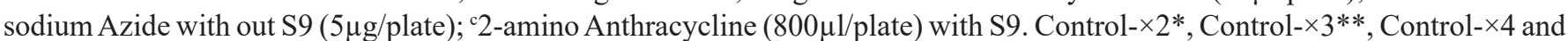
above $^{* * *}$. *=Possible Mutagen;**=Significant Mutagen;***Highly Significant Mutagen 
the autophagy and increasing cytotoxicity. Celecoxib with radiotherapy has shown promising results by G2-M cell phase arrest and enhancement of cell apoptosis (Zhang et $a l ., 2014)$. Hence, molecular target therapy can be used to target advanced malignancies of certain types and carvedilol in combination with celecoxib can be an option in the treatment or prevention of neoplasm particularly in hypertensive patients.

The genotoxicity evaluation of carvedilol and celecoxib were assessed using single cell gel electrophoresis (Comet assay) on peripheral blood mononuclear cells. There is a paucity of information on the toxicity of carvedilol in literature. However, few shreds of evidence have been found in literature to support our data (Table II). Aruna and Krishnamurthy (1986) Suggested induction of a significant increase in the frequency of micronuclei observed in erythrocyte at higher dose levels of propanolol. Many years later Sedigh-Ardekani, Saadat and Saadat (2013) shared the same concern about the non-selective beta blockers. Our data indicates that significant tail formation was observed in all the test concentrations range of $0.78 \mu \mathrm{g} / \mathrm{mL}-200 \mu \mathrm{g} /$ $\mathrm{mL}$ of Carvedilol, when compared with negative control (Figure 3 ). On the contrary, DNA damage was only observed at concentrations $\geq 75 \mu \mathrm{g} / \mathrm{mL}$ for celecoxib. But at concentrations $<75 \mu \mathrm{g} / \mathrm{mL}$ the tail formation decreased momentously, showing class 0, insignificant damage (Figure 3). Moreover, the combination of carvedilol and celecoxib were subjected to SCGE for evaluation of their genotoxicity potentials. Out of all the tested concentrations four have shown significant $(\mathrm{p}<0.05)$ DNA damage (Table II). The reason of these concentrations for being conspicuous is because reported genotoxic concentrations fall under threshold value of combined $\mathrm{IC}_{50}(13.4: 47.9 \mu \mathrm{g} /$ $\mathrm{mL})$. Henceforth, these concentration may bring about DNA damage yet not kill them. The consolidated impact of DNA damage, DNA repair defects, and an inability to stop or slow down the cell cycle (Lord, Ashworth, 2012). Our results also suggest a synergetic genotoxicity when our test drugs were used in combinations (Figure 3). Previous studies carried out on effects of drugs in combinations also support our data (Carter et al., 2007, Guimaraes et al., 2003).

DNA damage and chromosomal aberration can be a major cause for the development and progression of cancer (Hagmar et al., 2004). To validate this claim we tested carvedilol and celecoxib against Salmonella typhi TA98 and TA 100 for the evaluation of their mutagenicity potential alone and in combinations (Table III). Individual test concentrations of carvedilol and celecoxib did not show any signs of mutation against either strains of
Salmonella typhi. Nevertheless, upon addition of metabolic activation system significant rise in mutagenic index was observed. The concentrations, which were mutagenic for TA-100, were almost equally mutagenic for TA-98. The three out of five concentrations used in this project have exhibited mild to moderate mutagenic potential (Table III). Carvedilol and Celecoxib combinations have shown significant $(\mathrm{P}<0.05)$ mutagenic potential, against negative control at following concentrations $3.12 .9 .73 \mu \mathrm{g} / \mathrm{mL}$, 6.25:18.75 $\mu \mathrm{g} / \mathrm{mL}$ and 12.5:37.5 $\mu \mathrm{g} / \mathrm{mL}$. Several reports regarding the mutagenic synergism by combination of drugs are in support of our data. (Mansky, 2003, Torres et al., 2007). For instance, in recent work of Fatima et al. (2013) emphasized that all anti-TB drugs, specifically in combination, possess substantial cytotoxic and mutagenic potential making TB patient more susceptible to cytotoxic and mutagenic effects of anti-TB drugs, which could produce further health complications. These collective data suggest genomic instability is one of the most pervasive characteristics of tumor cells and is probably the combined effect of DNA damage, tumor-specific DNA repair defects, and a failure to stop or stall the cell cycle before the damaged DNA is passed on to daughter cells, hence our drug combinations may cause host cell DNA damage and mutations, and impose a cancer risk.

\section{CONCLUSION}

These collective data suggest Genomic instability is one of the most pervasive characteristics of tumor cells and is probably the combined effect of DNA damage, tumor-specific DNA repair defects, and a failure to stop or stall the cell cycle before the damaged DNA is passed on to daughter cells, hence our drug combinations may cause host cell DNA damage and mutations, and impose a cancer risk. It was concluded from the results that combination of Carvedilol and Celecoxib can be mutagenic, genotoxic and cytotoxic. Professional medical advice should be recommended before taking these medications in combination. These drugs should be taken at low concentrations for a shortest period of time.

\section{ACKNOWLEDGEMENT}

The authors wants to thanks Dr Sohail Ejaz, Department of Clinical Neurosciences, Stroke Research group, University of Cambridge, UK for providing us with his valuable time for reviewing our work and sharing his valuable comments to point out our mistakes and improve the quality of our manuscript. 


\section{CONFLICT OF INTEREST}

We report no conflict of interest for the present paper

\section{REFERENCES}

Aghbali A, Moradi Abbasabadi F, Delazar A, Vosough Hosseini S, Zare Shahneh F, Baradaran B, Janani M. Induction of apoptosis and cytotoxic activities of Iranian orthodox Black Tea Extract (BTE) using in vitro models. Adv Pharm Bull. 2014;4(3):255-60.

Aruna N, Krishnamurthy NB. Mutagenic evaluation of propranolol in somatic and germ cells of mice. Mutat Res. 1986;173(3):207-10.

Buckley LA, Dorato MA. High dose selection in general toxicity studies for drug development: a pharmaceutical industry perspective. Regul Toxicol Pharmacol. 2009;54(3):301-7.

Carter MM, Torres SM, Cook DLJr., McCash CL, Yu M, Walker VE, Walker DM. Relative mutagenic potencies of several nucleoside analogs, alone or in drug pairs, at the HPRT and TK loci of human TK6 lymphoblastoid cells. Environ Mol Mutag. 2007;48(3-4):239-47.

Cheng JS, Huang CC, Chou CT, Jan CR. Mechanisms of carvedilol-induced $[\mathrm{Ca} 2+] \mathrm{i}$ rises and death in human hepatoma cells. Nayn Schebrgs Arch Pharmacol. 2007;376(3):185-94.

Erguven M, Yazihan N, Aktas E, Sabanci A, Li CJ, Oktem G, Bilir A. Carvedilol in glioma treatment alone and with imatinib in vitro. Int J Oncol. 2010;36(4):857-66.

Fatima R, Ashraf M, Ejaz S, Rasheed MA, Altaf I, Afzal M, Batool Z, Saleem U, Anwar K. In vitro toxic action potential of anti tuberculosis drugs and their combinations. Environ Toxicol Pharmacol. 2013;36(2):501-13.

Fergus IV, Connell KL, Ferdinand KC. A comparison of vasodilating and non-vasodilating beta-blockers and their effects on cardiometabolic risk. Curr Cardiol Rep. 2015;17(6):1-6.

Gerli R, Sherer Y, Vaudo G, Schillaci G, Gilburd B, Giordano A, et al. Early atherosclerosis in rheumatoid arthritis: effects of smoking on thickness of the carotid artery intima media. Ann NY Acad Sci. 2005;1051:281-90.
Guimaraes AP, Dias FL, Cardoso RS, Kronka SN, SakamotoHojo ET. Chromosomal aberrations induced by 5 -azacytidine combined with VP-16 (etoposide) in CHO-K1 and XRS-5 cell lines. Teratog Carcinog Mutagen. 2003;Suppl 1:171-86.

Hagmar L, Strömberg U, Bonassi S, Hansteen I-L, Knudsen LE, Lindholm C, Norppa H. Impact of types of lymphocyte chromosomal aberrations on human cancer risk results from Nordic and Italian cohorts. Cancer Res. 2004;64(6):2258-63.

Jonsson O, Behnam-Motlagh P, Persson M, Henriksson R, Grankvist $\mathrm{K}$. Increase in doxorubicin cytotoxicity by carvedilol inhibition of P-glycoprotein activity. Biochem Pharmacol. 1999;58(11):1801-6.

Lord CJ, Ashworth A. The DNA damage response and cancer therapy. Nature. 2012;481:287-294.

Mancia G, Laurent S, Agabiti-Rosei E, Ambrosioni E, Burnier M, Caulfield MJ, et al. Reappraisal of European guidelines on hypertension management: a European Society of Hypertension Task Force document. J Hypertens. 2009;27:2121-58.

Mansky LM. Mutagenic outcome of combined antiviral drug treatment during human immunodeficiency virus type 1 replication. Virology. 2003;307(1):116-21.

Mills KT, Bundy JD, Kelly TN, Reed JE, Kearney PM, Reynolds $\mathrm{K}$, Chen J, He J. Global disparities of hypertension prevalence and control clinical perspective. Circulation. 2016;134:441-50.

Mortelmans K, Zeiger E. The Ames Salmonella/microsome mutagenicity assay. Mutat Res. 2000;455(1-2):29-60.

Mosmann T. Rapid colorimetric assay for cellular growth and survival: application to proliferation and cytotoxicity assays. J Immunol Meth. 1983;65(1-2):55-63.

Ohno M, Abe T. Rapid colorimetric assay for the quantification of leukemia inhibitory factor (LIF) and interleukin-6 (IL-6). J Immunol Meth. 1991;145(1-2):199-03.

Ouellet M, Riendeau D, Percival MD. A high level of cyclooxygenase-2 inhibitor selectivity is associated with a reduced interference of platelet cyclooxygenase-1 inactivation by aspirin. Proc Natl Acad Sci USA. 2001;98(25):14583-8.

Panoulas VF, Metsios GS, Pace AV, John H, Treharne GJ, Banks MJ, Kitas GD. Hypertension in rheumatoid arthritis. J Rheumatol. 2008;47(9):1286-98. 
Renna NF, de las Heras N, Miatello RM. Pathophysiology of vascular remodeling in hypertension. Int J Hypertens. 2013;2013:id808353.

Savoia C, Schiffrin EL. Inflammation in hypertension. Curr Opin Nephrol Hypertens. 2006;15(2):152-8.

Sedigh-Ardekani M, Saadat I, Saadat M. Propranolol induced chromosomal aberrations in Chinese hamster ovary cell line. Mol Cell Biol Res Commun. 2013;2(2):11-18.

Singh NP, McCoy MT, Tice RR, Schneider EL. A simple technique for quantitation of low levels of DNA damage in individual cells. Exp Cell Res. 1988;175(1):184-91.

Tarr G, Reuter H. Review of the safety of nonsteroidal antiinflammatory drugs and selective cyclo-oxygenase-2 inhibitors. South Afr Fam Pract. 2015;57(3):18-21.

Torres SM, Walker DM, Carter MM, Cook DL, McCash CL, Cordova EM, Olivero OA, Poirier MC, Walker VE. Mutagenicity of zidovudine, lamivudine, and abacavir following in vitro exposure of human lymphoblastoid cells or in utero exposure of CD-1 mice to single agents or drug combinations. Environ Mol Mutag. 2007;48(3-4):224-38. van Walsem A, Pandhi S, Nixon RM, Guyot P, Karabis A, Moore RA. Relative benefit-risk comparing diclofenac to other traditional non-steroidal anti-inflammatory drugs and cyclooxygenase- 2 inhibitors in patients with osteoarthritis or rheumatoid arthritis: a network meta-analysis. Arthritis Res Ther. 2015;17:66-73.

Xu H-B, Shen F-M, Lv Q-Z. Celecoxib enhanced the cytotoxic effect of cisplatin in chemo-resistant gastric cancer xenograft mouse models through a cyclooxygenase-2-dependent manner. Eur J Pharmacol. 2016;776:1-8.

Zhang S-X, Qiu Q-H, Chen W-B, Liang C-H, Huang B. Celecoxib enhances radiosensitivity via induction of $\mathrm{G} 2-\mathrm{M}$ phase arrest and apoptosis in nasopharyngeal carcinoma. Cell Physiol Biochem. 2014;33(5):1484-97.

Zuo C, Qiu X, Liu N, Yang D, Xia M, Liu J, et al. Interferonalpha and cyclooxygenase-2 inhibitor cooperatively mediates TRAIL-induced apoptosis in hepatocellular carcinoma. Exp Cell Res. 2015;333(2):316-26.

Received for publication on $05^{\text {th }}$ June 2017 Accepted for publication on $20^{\text {th }}$ September 2017 